\title{
Conference paper:
}

TRIP: The Economic and Environmental Consequences of Regulating Traffic

Research Conference in Hillerød 2-3 February 2003

\section{Car-use habits: An obstacle to the use of public transportation?}

Berit Møller \& John Thøgersen

Aarhus School of Business, Department of Marketing

Haslegaardsvej 10, 8210 Aarhus V, Denmark

$\mathrm{Tel}+458948$ 6688. Fax +4586153988

E-mail btm@asb.dk \& jbt@asb.dk 


\section{Car-use habits: An obstacle to the use of public trans- portation?}

\section{ABSTRACT}

It is often claimed that many drivers use their private car rather habitually. The claim obtains credibility from the fact that travelling to many everyday destinations fulfils all the prerequisites for habit formation: it is recurring, performed under stable circumstances, and produces rewarding consequences. Since the decision is made rather automatically and only one choice alternative is considered (the habitually chosen one) behaviours guided by habit are difficult to change. The implications of car-use habits for converting drivers to commuters by public transportation is analysed based on a survey in the Copenhagen area, collected in October 2002. The study reveals that a relatively low percentage of drivers (10-20\%) intend to commute by public transportation in the near future, which is hardly a surprise. A hierarchical analysis, where reported use of public transportation is regressed onto intentions to do so, car-use habit, and the interaction between the two, confirms the theory-derived hypothesis that car-use habits act as an obstacle to transforming intentions to commute by public transportation into action. 


\section{INTRODUCTION}

Even though the average fuel consumption per car kilometre fell 11\% during the 1990s, $\mathrm{CO}_{2}$ emissions from road transport in Denmark increased $16 \%$, the reason being that the increase in kilometres driven (29\%) outperformed the fall in fuel consumption (Danmarks Statistik, 2002). This situation is not unique for Denmark, on the contrary. World wide, the rapid growth in car driving is a source of concern because of its both local and global environmental impacts (e.g., Mackenzie, 1997; OECD, 1996; Tolba \& ElKholy, 1992). Solving the traffic-related environmental problems is not easy, however. A wide range of regulations, system changes, and adaptations are needed, which can only be provided through the concerted effort of many parties, including car producers, providers of public transport services, public authorities, and users of transport products and services (e.g., Mackenzie, 1997; OECD, 1996; Sperling \& Shaheen, 1995; Vlek, Hendrickx, \& Steg, 1993; Vlek \& Steg, 1996). Final consumers, who in their private lives and for private purposes demand transport solutions, play one of the key roles. Person transport makes up the bulk of total transport, and private cars are increasingly and dominantly used (Danmarks Statistik, 2002; Mackenzie, 1997).

Private consumers of transport products and services are also the majority of voters in all countries. Hence, in a democratic society, whatever solution one could think of to relieve the environmental and societal burdens of transport, it stands or falls with the acceptance by these individuals, either as buyers of transport products and services or in the voting booth (Schlag \& Teubel, 1997). In this paper we focus on individuals in their former capacity. Since the bulk of person transport is made by individuals as private consumers, 
and since their dual capacity as consumers and voters makes it virtually impossible to effectively force people to change their transport behaviour, much more insight is needed into how people can be persuaded to accept more environment-friendly transport solutions (Steg \& Vlek, 1997; Tertoolen, Kreveld, \& Verstraten, 1998).

In recent years, Dutch (Aarts, Verplanken, \& Knippenberg, 1998; Verplanken, Aarts, Knippenberg, \& Knippenberg, 1994; Verplanken, Aarts, Knippenberg, \& Moonen, 1998) and Swedish (Gärling, Boe, \& Fujii, 2001) researchers, in particular, have made substantial advances in demonstrating the importance of habits for the choice of modes of transportation. Consistent with these findings a recent Danish study found that past behaviour is a stronger predictor of the use of public transportation than the attitude towards using public transportation, public transportation's ability to cover the individual's transport needs, and perceived social pressure to use public transportation (Thøgersen, 2001). If the travel-mode is generally chosen habitually, this has profound influence on the effectiveness of different means of persuasion (e.g., Aarts, Verplanken, \& Knippenberg, 1997; Assael, 1987; Ronis et al., 1989; Thøgersen \& Ölander, 2002).

There is no doubt that the commute to work by car has the potential to become habitual: it is frequently and extensively performed, usually in stable surroundings, and usually the destination is reached in a timely and comfortable manner, i.e., the experience is perceived as rewarding. These are the three prerequisites for habit formation identified, for instance, by Ouellette and Wood (1998). Conditions such as these facilitate a learning process, which allows the individual to reduce the amount of cognitive effort in decisionmaking and to perform the behaviour with increasing automaticity (Ouelette \& Wood, 1998; Thøgersen \& Ölander, 2002). 
Following Verplanken and Aarts (1999) we define a habit as a learned sequence of acts that has become an automatic response to specific cues, and is functional in obtaining certain goals or end-states. The instigation of a habitual behaviour is volitional and intentional, but subsequent acts may be unintentional (Ouellette \& Wood, 1998; Verplanken \& Aarts, 1999). Ouellette and Wood (1998) remark that many established behavioural routines in daily life, such as car use, have both volitional (e.g., planning to go somewhere) and automatic elements (e.g., picking the car, driving).

A habit, which was functional in obtaining some goal(s) at the time when it was formed, may loose its functionality if the goal(s) change at a later point in time (Verplanken \& Aarts, 1999). In such cases the habit may become counter-intentional. Counterintentional habits are particularly prevalent when the behaviour is based on short-term, hedonistic motives at the expense of long-term goals (Verplanken \& Faess, 1999). The impact of habits that counteract attitudes and intentions has been studied for healthy dieting behaviours (Verplanken \& Faess, 1999), but not previously in the domain of travelmode choice.

Studies of the habit-intention-behaviour relationships regarding travel-mode choice have confirmed Triandis's (1977; Landis, Triandis, \& Adamopoulos, 1978) theory that behavioural intentions and habits interact in determining behaviour, meaning that the stated intention is a good predictor of behaviour only under conditions of weak habits while intention is a bad predictor of behaviour when habits are strong (e.g., Aarts et al., 1997; Gärling et al., 2001; Verplanken et al., 1994; Verplanken et al., 1998). For instance, Verplanken et al. (1994) found that the correlation between the attitude towards a specific travel-mode option and travel-mode choice (for shopping trips to either of two cities lo- 
cated approximately 5 miles away and where a realistic public transport option existed) was significantly weaker for strong than for weak habit individuals.

This study is heavily inspired by studies by Verplanken and his associates (e.g., Verplanken et al., 1994; Verplanken et al., 1998). However, our angle is slightly different. We investigate whether a habit of using one travel mode (a private car) is an obstacle to choosing another (public transportation). Our approach is an attempt to investigate the influence of counter-intentional habits (Verplanken \& Aarts, 1999) on travel mode choice, where car-use habits are perceived as counter-intentional with respect to an intention to commute by public transportation. Specifically, we test the following hypothesis:

- H1: For commuters with strong car-use habits there is a weak correlation between intention and behaviour concerning the use of public transportation and for commuters with weak car-use habits the correlation is strong.

\section{METHOD}

This study is based on a survey of drivers in the Copenhagen area, collected in October 2002. Only $37.6 \%$ of the households in the Copenhagen area have a car (Danmarks Statistik, 2001). Hence, rather than aiming for a representative picture of the total population, this study focuses at the segment that is most likely to have developed a habit of commuting by private car. Respondents were screened according to the following criteria: The household has a car at its disposition and the respondent possesses a drivers licence, is in job or study, has not held a period-card for public transportation in the Co- 
penhagen area in the last year, and does not need a car to perform the job. If more than one person in the household fulfilled the criteria, the next birthday method was used to select the respondent.

Of those meeting the screening criteria 1071 agreed to participate, resulting in a response rate of 75 percent of those meeting the criteria. Listwise deletion is used in case of missing values meaning that the sample size is reduced by from 27 to 73 respondents in the following analyses.

\section{DATA}

Behaviour was measured as a frequency on a scale from 0 to 10 with the item:

How many of the last 10 times have you used public transportation for the trip between home and work/educational institution?

Although low, the mean of the behaviour $(.57$, std. $=1.90, \mathrm{n}=1070)$ differ significantly from zero $(\mathrm{t}=9.832, \mathrm{p}<0.001)$. A frequency analysis shows that $85 \%$ of the respondents had not commuted by public transportation one single time out of the last ten, $8 \%$ had used public transportation one or two times and $7 \%$ more than two times out of the last ten commutes.

The intention to commute by public transportation was measured with two items on 11point scales, following the form suggested by Ajzen and Fishbein (1980) (see Table 1).

\footnotetext{
${ }^{1}$ Notice that the measure of behaviour frequency is thus taken at the same time as the measure of behavioural intention. Hence, as always in cross-sectional analyses, the measures are not registered in their assumed temporal sequence. This, of course, means that we cannot be sure about the direction of causality between the measured variables. However, previous studies have found travel mode choices to be quite stable over time (Bamberg \& Lüdemann, 1996), even over a period of one year (Thøgersen, 2001), which indicates that using behaviour in the near past as an indicator for behaviour in the near future is indeed defensible in the present case.
} 
The intention scale is constructed by averaging the scores on the two items. Cronbach's Alpha indicates excellent reliability. The scale mean is significantly different from zero ( $t$ $=9.820, \mathrm{p}<0.001)$. A frequency analysis shows that $89 \%$ of the respondents did not plan to commute by public transportation one single time out of the next ten and $81 \%$ did not expect to commute by public transportation at all during the following month.

Two habit measures were employed. The response frequency (RF) measure developed by Verplanken and his associates (1994) attempts to capture mental representations of habitual activities. It is based on the assumption that habitual responses are guided by mental representations of past behaviour, i.e., scripts or schemas (Aarts et al., 1997). When a habit appears in different contexts (e.g., habitual car use in shopping, recreational and/or work-related contexts), each of the contexts may evoke its own specific scripted sequence of acts (Verplanken \& Aarts, 1999). Still, if the goal and the behavioural response is the same, a general habit may evolve that is capable of being triggered by specific cues in different situations. The RF measure is designed to capture such a general habit, rather than the habit of choosing a particular travel mode in a particular situation.

In order to get access to scripts in the semantic memory, the RF measure attempts to elicit automatic (as opposed to strategic) responses. Automatic responses are facilitated by imposing time pressure and by asking about the first travel mode that comes to mind when confronted with the choice situation (Aarts et al., 1997; Verplanken \& Aarts, 1999). The instrument contains 10 trips of short, medium, or long distance. The number of times that 
"car" is mentioned serves as a measure of the respondent's general habit of choosing the car. Hence, the RF measure varies from 0 to 10. Items are presented in Table 2.

Insert Table 2 around here

The other habit measure, the self-reported habit index (SRHI), was recently developed by Verplanken and Orbell (2001). It attempts to capture the features of automaticity assumed to be most descriptive of a habit: uncontrollability, efficiency, and lack of awareness, in addition to a history of repetition and the degree of reflecting identity or personal style. Verplanken and Orbell had 12 items in their original instrument. Here, the number of items was reduced, after a pre-test, to 7 items. The items are presented in Table 3.

Insert Table 3 around here

The SRHI scale is constructed by averaging the scores on the seven items. Cronbach's Alpha indicates excellent reliability.

\section{RESULTS}

The hypothesis that for commuters with strong car-use habits there is a weak correlation between intention and behaviour concerning public transportation, and for commuters with weak car-use habits the correlation is strong is tested by means of hierarchical regression analysis. In a hierarchical regression analysis, the independent variables are entered in the order that one expects them to influence the dependent variable. In this case it is assumed, that the intention to use public transportation is the immediate antecedent of this behaviour, if not blocked by car-use habits. Hence, when predicting commuting by 
public transportation, the intention to use public transportation is entered first followed by a measure of car-use habits. In this second step a possible additive effect of habit on behaviour are captured. Finally, the hypothesised moderating effect of habit on the intention-behaviour relationship are captured by including the interaction term intention*habit in the equation. Hence, the analysis involves three steps:

1. $\quad$ Behaviour $=\mathrm{f}($ Intention $)$

2. $\quad$ Behaviour $=\mathrm{f}($ Intention, Habit $)$

3. Behaviour $=\mathrm{f}($ Intention, Habit, Intention*Habit $)$

If the F-value of the change in $\mathrm{R}^{2}$ from one step to the next is statistically significant it shows that the entered variable has a significant effect on the dependent variable not accounted for by the previously entered variable(s).

In order to avoid multicollinearity, the intention and habit measures were centred (that is, scores changed to deviations from the scale mean) before conducting the analysis (Aiken \& West, 1991; Cronbach, 1987). First, we present the results of the analysis using the SRHI measure of habit (Table 4).

Insert Table 4 around here

Table 4 shows that the model predicts behaviour satisfactorily (53\% explained variance). The standardized $\square$-coefficients reveal, as expected, a significant and positive direct effect of intention on behaviour. Also as expected, the direct effect of car-use habit on commuting by public transportation (behaviour) is negative, but it is not significant at the .05-level. And as predicted there is a significant interaction between car-use habit and 
intention. The $\square$-coefficient of the interaction term shows how much the effect of one of the variables depends on the level of the other. In the presence of an interaction effect, the $\square$-coefficient of a centred variable represents its effect at the mean of the interacting variable (Aiken \& West, 1991). At one standard deviation above (below) the mean of the interacting variable the $\square$-coefficient of the variable in focus is equal to its value at the mean of the interacting variable plus (minus) the coefficient of the interaction term. Hence, when the car-use habit is strong (one standard deviation above its mean value) the effect of intention on behaviour is a weak .37 (i.e., .58 + (-.21)) and when the car-use habit is weak (one standard deviation below its mean value) the effect of intention on behaviour is a strong .79 (i.e., $.58-(-.21)$ ), consistent with the hypothesis that car-use habits act as an obstacle to transforming intentions to commute by public transportation into action.

An analogues hierarchical regression analysis was made with the RF measure representing habit. The results are shown in Table 5.

\section{Insert Table 5 around here}

Again, the model predicts behaviour satisfactorily (50\% explained variance), although not as well as the former. The reason for the difference is that effect of the interaction term is weaker when the RF than when the SHRI measure represents habit. However, the interaction term still has a (marginally) significant negative effect in this case. Hence, substantively the conclusions of the analysis remain the same: that intentions to commute by public transportation are more likely to be transformed into action under conditions of weak than under conditions of strong car habits. 


\section{SUMMARY AND IMPLICATIONS}

Based on reasoning suggesting that it is likely that car-users develop a habit of commuting by car and on previous research suggesting that travel-mode choices are strongly influenced by habits, this study sets out to investigate whether a habit of driving may be an obstacle to transforming an intention to commute by public transportation into action. In this perspective, a car-use habit may be conceived as counter-intentional. The study is based on a survey of car-users in the Copenhagen area. Behaviour is operationalised as behaviour frequency, behavioural intention as a plan for the near future, and habits as either a general, cross-situational script linking transport goals to a travel-mode (the response frequency measure) or as a more specific self-descriptive measure regarding commuting by car that captures features of automaticity, a history of repetition, and the degree to which commuting by car reflects identity or personal style (the self-reported habit index).

Two results of the analyses are particularly noteworthy:

(1) Descriptive statistics show that only $10-20 \%$ of the interviewed car-users have any intention to commute by public transportation in the near future and that equally few have done so in the recent past. This should come as no surprise. Many drivers commute by car because there are no alternatives that fulfil their specific needs and probably an even larger number do it because they perceive the car as the best among available alternatives. Of course, some of them may be wrong, that is, they may be ill-informed about the options available to them. However, our focus is not on the ill-informed, but on the minority of drivers that 
have formed a conscious intention to commute by public transportation. Is a caruse habit an obstacle to transforming such an intention into action?

(2) Hierarchical regression analysis shows that intentions and behaviour regarding commuting by public transportation are quite strongly correlated. However, as predicted by the proposition that car-use habits form an obstacle to transforming an intention to commute by public transportation into action, the intentionbehaviour correlation depends on the strength of the habit of driving by car. When the habit is weak, the intention-behaviour correlation is strong, and when the habit is strong, the intention-behaviour correlation is weak(er). This is the result disregarding which of the two included habit measures is used, but the strength of the moderator effect varies between the two measures. The SRHI measure is a considerably stronger moderator than the RF measure.

We cannot be sure why the two habit measures are not equally strong moderators of the commuting by public transportation intention-behaviour relationship. Evidence presented in Table 2 above suggests that the most likely reason is that few drivers have developed a cross-situational habit of driving by car that is as general as suggested by the RFmeasure, however. Table 2 shows that the percentage of drivers picking the car as their chosen mode of transportation to the ten destinations varies a lot (from 30.5 to 95.1\%). Hence, it seems likely that the RF-instrument contains situations not covered by most of the analysed drivers' car habits. This could explain why the RF measure is a weaker moderator than the SRHI measure, which focuses specifically on car-use for commuting ${ }^{2}$ (cf. the discussion about the correspondence principle in attitude theory (Ajzen \& Fish-

\footnotetext{
${ }^{2}$ In fact, commuting is not even included among the situations covered by the RF measure.
} 
bein, 1980). If this is the explanation the RF-measure should become a stronger moderator of the intention-behaviour relationship if items diverging from the general pattern were removed. In the calculations reported in Table 6 we removed the three situations where fewer than $50 \%$ responded that they would use the car. As can be seen, this leads to an increase in the numerical value of the regression coefficient of the interaction term and to the inclusion of the interaction term leading to a highly significant increase in $\mathrm{R}^{2}$. This obviously lends support to our proposed explanation for the weakness of the RF measure.

Insert Table 6 around here

Previous research and reasoning about the nature of decision-making regarding habitual behaviours suggest that information about opportunities for and the benefits of public transportation stands small chances of breaking a habit of commuting by car e.g., (Gärling \& Axhausen, 2003; Verplanken et al., 1998). Instead, we suggest that there is a need to explore the possibilities for implementing structural changes that are both strong enough to force or entice car-users to at least try available public transportation options and acceptable for car-users (voters) as well as for politicians. In our current research we test the effectiveness of a temporary economic incentive in the form of an offer to use public transportation free of charge for one month, but there are many other possibilities that should be pursued. 


\section{REFERENCES}

Aarts, H., Verplanken, B., \& Knippenberg, A. v. (1997). Habit and information use in travel mode choices. Acta Psychologica, 96, 1-14.

Aarts, H., Verplanken, B., \& Knippenberg, A. v. (1998). Predicting behavior from actions in the past: Repeated decision making or a matter of habit. Journal of Applied Social Psychology, 28, 1355-1374.

Aiken, L. S., \& West, S. G. (1991). Multiple regression: Testing and interpreting interactions. Newbury Park: Sage Publications.

Ajzen, I., \& Fishbein, M. (1980). Understanding attitudes and predicting social behavior. Englewood Cliffs: Prentice-Hall.

Assael, H. (1987). Consumer behavior and marketing action. Boston: Kent Publishing Co.

Bamberg, S., \& Lüdemann, C. (1996). Eine Überprüfung der Theorie des geplanten Verhaltens in zwei Wahlsituationen: Rad vs. Pkw und Container vs. Hausmüll. Zeitschrift für Sozialpsychologie, 27, 32-46.

Bargh, J. A., \& Barndollar, K. (1996). Automaticity in action: The unconscious as repository of chronic goals and motives. In J. A. Bargh \& P. Golwitzer (Eds.), Psychology of action (pp. 457-481). New York: Guilford.

Cronbach, L. (1987). Statistical tests for moderator variables: flaws in analyses recently proposed. Psychological Bulletin, 102, 414-417. 
Danmarks Statistik. (2001). Familiernes bilrådighed 2001. København: Danmarks Statistik.

Danmarks Statistik. (2002). CO2-udledning fra vejtransport er steget (Nyt fra Danmarks Statistik: Trafik og miljø 2002 477). København: Danmarks Statistik.

Gärling, T., \& Axhausen, K. W. (2003). Introduction: Habitual travel choice. Transportation, 30, 1-11.

Gärling, T., Boe, O., \& Fujii, S. (2001). Empirical tests of a model of determinants of script based driving choice. Transportation Research F, 4, 89-102.

Landis, D., Triandis, H. C., \& Adamopoulos, J. (1978). Habit and behavioral intentions as predictors of social behavior. Journal of Social Psychology, 106, 227-237.

Mackenzie, J. J. (1997). Driving the road to sustainable ground transportation. In R. Dower \& D. Ditz \& P. Faeth \& N. Johnson \& K. Kozloff \& J. J. Mackenzie (Eds.), Frontiers of sustainability (pp. 121-190). D.C. Washington: Island Press.

OECD. (1996). Towards sustainable transportation. The Vancouver conference. Paris: OECD.

Ouellette, J. A., \& Wood, W. (1998). Habit and intention in everyday life: The multiple processes by which past behavior predicts future behavior. Psychological Bulletin, 124, 54-74.

Ronis, D. L., Yates, J. F., \& Kirscht, J. P. (1989). Attitudes, decisions, and habits as determinants of repeated behavior. In A. R. Pratkanis \& S. J. Breckler \& A. G. 
Greenwald (Eds.), Attitude structure and function (pp. 213-239). Hillsdale, N.J.: Lawrence Erlbaum.

Rothenborg, M., \& Jensen, W. H. (2002, 21/6). Spring en kort køretur over. Politiken, pp. 4.

Schlag, B., \& Teubel, U. (1997). Public acceptability of transport pricing. IATSS research, 21(2), 134-142.

Sperling, D., \& Shaheen, S. A. (Eds.). (1995). Transportation and energy: Strategies for a sustainable transportation system. Washington, D. C. and Berkley, California: American Council for an Energy-Efficient Economy.

Steg, L., \& Vlek, C. (1997). The role of problem awareness in willingness-to-cange car use and in evaluating relevant policy measures. In T. Rothengatter \& E. C. Vaya (Eds.), Traffic \& transport psychology. Theory and application (1 ed., pp. 465475; chap. 448): Pergamon.

Tertoolen, G., Kreveld, D. V., \& Verstraten, B. (1998). Psychological resistance against attempts to reduce private car use. Transportation Research-A, 32, 171-181.

Thøgersen, J. (2001). Structural and psychological determinants of the use of public transport. Paper presented at the the Second Annual TRIP colloquium 14-15 November 2001, Sophienberg Slot, Hørsholm.

Thøgersen, J., \& Ölander, F. (2002). The interaction between environmental norms and behaviour: A panel study of organic food consumption. Submitted for review. 
Tolba, M. K., \& El-Kholy, O. A. (Eds.). (1992). The world environment 1972-1992. Two decades of challenge. London: Chapman \& Hall on behalf of UNEP.

Trafikministeriet. (1995). Transportsektorens miljøbelastning (rapport): Trafikministeriet.

Trafikministeriet. (1999). Begraensning af transportsektorens CO2 udslip. København: Trafikministeriet.

Triandis, H. C. (1977). Interpersonal behavior. Monterey: Books/Cole.

Verplanken, B., \& Aarts, H. (1999). Habit, attitude, and planned behaviour: Is habit an empty construct or an interesting case of goal-directed automaticity? European Review of Social Psychology, 10, 101-134.

Verplanken, B., Aarts, H., Knippenberg, A. v., \& Knippenberg, C. v. (1994). Attitude versus general habit: Antecedents of travel mode choice. Journal of Applied Social Psychology, 24, 285-300.

Verplanken, B., Aarts, H., Knippenberg, A. v., \& Moonen, A. (1998). Habit versus planned behavior: A field experiment. British Journal of Social Psychology, 37, 111-128.

Verplanken, B., \& Faess, S. (1999). Good intentions, bad habits, and effects on forming implementation intentions on healthy eating. European Journal of Social Psychology, 29, 591-604. 
Verplanken, B., \& Orbell, S. (2001). Reflections on past behaviour: A self-report index of habit strength. Submittet for review.

Vlek, C., Hendrickx, L., \& Steg, L. (1993). A social dilemma analysis of motorised transport problems and six general strategies for social behaviour change, European conference of ministers of transport (pp. 210-225). Paris: ECMT Publications.

Vlek, C., \& Steg, L. (1996). Societal reasons, conditions and policy strategies for reducing the use of motor vehicles: a behavioural-science perspective and some empirical data. In OECD (Ed.), Towards sustainable transportation (pp. 2-9). Paris: OECD. 
Table 1: Items and descriptive statistics for intention

\begin{tabular}{lccc}
\hline$(\mathrm{n}=1052)$ & Mean & Std & Alpha \\
\hline $\begin{array}{l}\text { How many of the next 10 times do you plan to use public } \\
\text { transportation for the trip to work/educational institution? }\end{array}$ & 0.44 & 1.68 & \\
$\begin{array}{l}\text { (0: zero times - 10: ten times) } \\
\text { If you look at the next month, of often do you think you }\end{array}$ & 0.54 & 1.70 & \\
$\begin{array}{l}\text { will use public transportation for the trip to } \\
\text { work/educational institution? (0: never to 10: every time) }\end{array}$ & & & \\
\hline SCALE intention & 0.49 & 1.62 & 0.92 \\
\hline
\end{tabular}


Table 2: Items and descriptive statistics for the response frequency habit measure (RF)

\begin{tabular}{lcc}
\hline $\begin{array}{l}\text { I now mention some travel mode situations. Please mention as fast as possible for } \\
\text { each of them the travel mode that springs to mind. There are no wrong answers, } \\
\text { but it is important that you answer as quickly as you can, and mention the trans- } \\
\text { portation mode that first comes to mind. Which mode of transportation would } \\
\text { you choose if ... }\end{array}$ & $\begin{array}{c}\text { \% choosing } \\
\text { car }\end{array}$ & $\mathrm{n}$ \\
\hline $\begin{array}{l}\text { picking someone at the central station? } \\
\text { visiting someone in the other end of the capital area? }\end{array}$ & 77.4 & 1065 \\
going to the beach with friends for a day? & 84.8 & 1064 \\
going shopping in the centre of Copenhagen? & 76.4 & 1063 \\
going to the nearest wood for at walk? & 33.8 & 1063 \\
going to sports or other recreational activities? & 70.6 & 1067 \\
going shopping in the nearest supermarket? & 55.3 & 1054 \\
going to the nearest post office? & 43.6 & 1070 \\
going to visit someone in Jutland? & 30.5 & 1069 \\
going to visit a sight outside the Copenhagen area? & 79.0 & 1059 \\
\hline Scale RF (mean = 6.48, std, = 2.12) & 95.1 & 1068 \\
\hline
\end{tabular}


Table 3: Items and descriptive statistics for the of SRHI-measure, $\mathrm{n}=1064$

\begin{tabular}{|c|c|c|c|}
\hline & Mean & Std & Alpha \\
\hline $\begin{array}{l}\text { I often use car as mean of transportation between home and } \\
\text { work/educational institution }\end{array}$ & 3.86 & 1.67 & \\
\hline $\begin{array}{l}\text { I automatically use car as mean of transportation between home and } \\
\text { work/educational institution }\end{array}$ & 3.57 & 1.78 & \\
\hline $\begin{array}{l}\text { It would be difficult not to use car as mean of transportation between } \\
\text { home and work/educational institution }\end{array}$ & 3.07 & 1.76 & \\
\hline $\begin{array}{l}\text { To use car as mean of transportation between home and } \\
\text { work/educational institution belongs to my routines }\end{array}$ & 3.66 & 1.74 & \\
\hline $\begin{array}{l}\text { I would find it hard not to use car as mean of transportation between } \\
\text { home and work/educational institution }\end{array}$ & 3.20 & 1.76 & \\
\hline $\begin{array}{l}\text { To use car as mean of transportation between home and } \\
\text { work/educational institution is something that is typically me }\end{array}$ & 3.35 & 1.73 & \\
\hline $\begin{array}{l}\text { To use car as mean of transportation between home and } \\
\text { work/educational institution is something I have done for a long time. }\end{array}$ & 3.68 & 1.75 & \\
\hline SCALE: habit (SRHI) & 3.09 & 1.78 & 0.95 \\
\hline
\end{tabular}


Table 4. Hierarchical regression: The moderating effect of habit (SRHI) on the intentionbehaviour-relationship $(\mathrm{n}=1044)$

\begin{tabular}{lccrcc}
\hline & Adj. $\mathrm{R}^{2}$ & $\square \mathrm{R}^{2}$ & $\square \mathrm{F}$ & \multicolumn{1}{c}{ d.f. } & Sig. $\square \mathrm{F}$ \\
\hline $1: \mathrm{B}=\mathrm{f}(\mathrm{I})$ & 0.50 & & & & 0.000 \\
2: $\mathrm{B}=\mathrm{f}(\mathrm{I}, \mathrm{H})$ & 0.50 & 0.000 & 0.346 & $1 ; 1041$ & 0.580 \\
$3: \mathrm{B}=\mathrm{f}\left(\mathrm{I}, \mathrm{H}, \mathrm{I}^{*} \mathrm{H}\right)$ & 0.53 & 0.028 & 60.772 & $1 ; 1040$ & 0.000 \\
\hline
\end{tabular}

Note: $\mathrm{H}=$ car-habit (SRHI measure), $\mathrm{B}$ = behaviour: use of public transportation, I = intention to use public transportation.

Estimated parameters for equation 3:

Behaviour $=0.58 \mathrm{I}-0.04 \mathrm{H}-0.21(\mathrm{I} * \mathrm{H}) ;$ parameters for $\mathrm{I}$ and $\mathrm{I} * \mathrm{H}$ are significant at $\mathrm{p}<.001$. 
Table 5: Hierarchical regression: The moderating effect of habit (RF) on the Intentionbehaviour-relation $(\mathrm{n}=998)$

\begin{tabular}{llllll}
\hline & Adj. $\mathrm{R}^{2}$ & $\square \mathrm{R}^{2}$ & $\square \mathrm{F}$ & d.f. & Sig. $\square \mathrm{F}$ \\
\hline $1: \mathrm{B}=\mathrm{f}(\mathrm{I})$ & 0.499 & & & & \\
$2: \mathrm{B}=\mathrm{f}(\mathrm{I}, \mathrm{H})$ & 0.498 & 0.000 & 0.064 & $1 ; 995$ & 0.800 \\
$3: \mathrm{B}=\mathrm{f}\left(\mathrm{I}, \mathrm{H}, \mathrm{I}^{*} \mathrm{H}\right)$ & 0.500 & 0.002 & 3.425 & $1 ; 994$ & 0.065 \\
\hline
\end{tabular}

Note: $\mathrm{H}=$ car-habit (RF measure), $\mathrm{B}=$ behaviour: use of public transportation, I = intention to use public transportation.

Estimated parameters for equation 3:

Behaviour $=0.68 \mathrm{I}-0.01 \mathrm{H}-0.05\left(\mathrm{I}^{*} \mathrm{H}\right)$; parameters for $\mathrm{I}$ and $\mathrm{I}^{*} \mathrm{H}$ are significant at $\mathrm{p}<.001$ and $\mathrm{p}<.07$ respectively. 
Table 6: Hierarchical regression: The moderating effect of habit (revised RF-scale) on the Intention-behaviour-relation $(\mathrm{n}=998)$

\begin{tabular}{llllll}
\hline & Adj. $\mathrm{R}^{2}$ & $\square \mathrm{R}^{2}$ & $\square \mathrm{F}$ & d.f. & Sig. $\square \mathrm{F}$ \\
\hline $1: \mathrm{B}=\mathrm{f}(\mathrm{I})$ & 0.499 & & & & \\
2: $\mathrm{B}=\mathrm{f}(\mathrm{I}, \mathrm{H})$ & 0.499 & 0.000 & 0.588 & $1 ; 995$ & 0.444 \\
3: $\mathrm{B}=\mathrm{f}\left(\mathrm{I}, \mathrm{H}, \mathrm{I}^{*} \mathrm{H}\right)$ & 0.503 & 0.005 & 9.116 & $1 ; 994$ & 0.003 \\
\hline
\end{tabular}

Note: $\mathrm{H}=$ car-habit (revised RF measure), $\mathrm{B}=$ behaviour: use of public transportation, $\mathrm{I}=$ intention to use public transportation.

Estimated parameters for equation 3:

Behaviour $=0.67 \mathrm{I}-0.01 \mathrm{H}-0.08\left(\mathrm{I}^{*} \mathrm{H}\right) ;$ parameters for $\mathrm{I}$ and $\mathrm{I}^{*} \mathrm{H}$ are significant at $\mathrm{p}<.001$ and $\mathrm{p}<.003$ respectively. 